\title{
Comparing Customer Satisfaction across Industries and Countries
}

\author{
Michael D. Johnson, Ph.D. ${ }^{1}$, Andreas Herrmann, Ph.D. ${ }^{2}$, Anders Gustafsson, Ph.D. ${ }^{3}$ \\ ${ }^{1}$ University of Michigan Business School, 701 Tappan Street, Ann Arbor, MI 48109-1234, USA \\ ${ }^{2} \mathrm{MCM}$ Institute, Universität St. Gallen, Blumenbergplatz 9, CH-9000 St. Gallen, Switzerland \\ ${ }^{3}$ Service Research Center, Karlstad University, 65188 Karlstad, Sweden
}

\begin{abstract}
Although aggregate satisfaction measures continue to proliferate, their value in making broadbased comparisons remains unclear. This study uses arguments from the economics, psychology, sociology and marketing domains to predict systematic differences in aggregate customer satisfaction across both industries and countries. These predictions are tested using a database created from three broad-based national satisfaction surveys in Sweden, Germany and the United States. The results reveal that, across countries, satisfaction is highest for competitive products, lower for competitive services and retailers, and lower still for government and public agencies. However, the differences vary by country. Satisfaction is also predictably lower in Sweden and Germany compared to the US, and shown to change systematically in Sweden over time. Methodological differences do not appear to limit the comparability of the aggregate satisfaction measures. Overall the study supports the use of national indices for making meaningful comparisons of satisfaction on a broad scale.
\end{abstract}




\section{Introduction}

The last decade has witnessed a proliferation of aggregate measures of customer satisfaction in Sweden, Germany, the US, Norway, the EU, and a variety of other countries (Johnson, Gustafsson, Andreassen, Lervik, \& Cha, 2001). These measures have the potential to provide both managers and policy makers with broad-based benchmarks of performance ranging from how a firm performs within a category, to how an industry performs within an economy, to how an economy performs against other economies.

Yet the value of broad-based benchmarks remains unclear. Although the national indices have been shown to reveal systematic differences in satisfaction across different types of industries within particular countries (Fornell, Johnson, Anderson, Cha, \& Bryant, 1996), the generality of these differences and their value in making comparisons across countries has not been tested. For example, in the United States, public and government agencies provide lower levels of satisfaction than more competitive product and service industries. Whether such differences generalize to countries like Sweden, where government agencies are arguably more customer focused, remains unclear. And while there are reasons to support the use of customer satisfaction as a broad-based performance benchmark (Fornell \& Johnson, 1993; Johnson \& Fornell, 1991), public policy researchers contend that such comparisons are psychologically problematic (Olander, 1988). From a practical standpoint, it is also unclear just how comparable results are across countries when satisfaction is aggregated using different methods and measures. Satisfaction in Germany is, for example, measured very differently than in Sweden or the United States.

A primary goal of this research is to examine whether industry differences observed in earlier studies generalize across countries. We combine arguments from economics, psychology, sociology and marketing to predict systematic differences in satisfaction across both industries and countries. We then use a unique database created from three established national satisfaction surveys in Sweden (the Swedish Customer Satisfaction Barometer or SCSB; Fornell, 1992), Germany (the Deutsche Kundenbarometer or DK; Meyer, 1994, 1996), and the United States (the American Customer Satisfaction Index or ACSI; Fornell et al., 1996) to test the hypotheses. The results support systematic similarities as well as differences in satisfaction from country to country. Another important finding is that methodological differences do not appear to limit the comparability of the satisfaction measures. Overall the results have important implications for both managers and policy makers who use satisfaction measures to evaluate the competitiveness of firms, industries, and entire countries.

\section{Aggregation and broad-based comparisons of satisfaction}

Broad-based measures of satisfaction benefit from different dimensions of aggregation. Epstein $(1979,1980)$ describes "four faces of aggregation" that encompass aggregation over subjects, stimuli, occasions and measures. Johnson (1995) argues that these four faces have important implications for the comparability of customer satisfaction scores. Averaging over different subjects or customers should increase the stability and resulting comparability of satisfaction measures, as individual differences become self-canceling random factors (Katona, 1975). The same is true for aggregation over stimuli, which in this context is the averaging of satisfaction over a range of products and services within a given industry or country. As with aggregation over subjects, aggregation over stimuli is a way of canceling out uncontrolled unique effects, which should make the satisfaction measures more comparable.

The other two faces, aggregation over occasions and measures, have direct implications for the choice of a satisfaction construct and its operationalization. Aggregating over occasions, 
in this case consumption experiences, cancels out incidental effects associated with particular occasions thus increasing temporal reliability. As detailed below, this makes cumulative satisfaction, or satisfaction over time, a better performance benchmark than transaction-specific satisfaction. Finally, aggregation over measures is more commonplace in customer satisfaction research, where multiple measures reduce measurement error when operationalizing satisfaction and loyalty as latent constructs (Churchill and Surprenant, 1982; Johnson \& Fornell, 1991). Overall, the four faces of aggregation suggest that meaningful comparisons of customer satisfaction are more likely when satisfaction measures are aggregated over customers, market offerings, usage occasions, and measures.

\subsection{Cumulative versus transaction-specific satisfaction}

Customer satisfaction research has developed around two different types of evaluations. transaction-specific satisfaction and cumulative satisfaction (Johnson, 2001). Transactionspecific satisfaction is a customer's evaluation of their experience with a particular product transaction, episode or service encounter. Early transaction specific research explored the cognitive-psychological antecedents of satisfaction, while more recent research has focused on the effects of positive and negative emotions on satisfaction (see Oliver, 1997). The cumulative approach defines satisfaction as a customer's overall experience with a product or service over occasions or time (Johnson, Anderson, \& Fornell, 1995; Johnson \& Fornell, 1991). Conceptually this is more consistent with treatments of customer satisfaction in both economic psychology (Johnson \& Fornell, 1991; Poiesz \& von Grumbkow, 1988; Warneryd, 1988) and welfare economics (Simon, 1974), where satisfaction is equivalent to consumption utility.

Johnson and Fornell (1991) speak specifically to the problem of constructing broadbased satisfaction measures and the resulting need to adopt a cumulative definition of satisfaction. They argue that cumulative satisfaction, as an overall evaluation of the consumption experience, should be viewed as a theoretical or latent variable (similar to an attitude). As a latent variable, satisfaction can be empirically measured and meaningfully compared as a weighted-average or index of satisfaction indicators. For example, in the American Customer Satisfaction Index model (see Fornell et al., 1996), satisfaction is a weighted average of three survey ratings. (1) an overall rating of satisfaction; (2) the degree to which performance falls short of or exceeds expectations; and (3) a rating of overall performance relative to the customer's ideal good or service in the category. The three measures provide a highly reliable and stable index of satisfaction.

It is important to keep in mind that cumulative satisfaction and transaction specific satisfaction are complementary rather than competing concepts (Johnson, 2001). An advantage of transaction-specific models is that they provide a rich understanding of the dynamics of product and service encounters or episodes (Oliver, 1997). But consistent with our discussion of aggregation, cumulative satisfaction takes advantage of aggregation over occasions as well as measures. Thus cumulative satisfaction should provide a reliable performance benchmark for making broad-based comparisons. Based on these arguments, the SCSB (Fornell, 1992), the ACSI (Fornell et al., 1996), the NCSB (Norwegian Customer Satisfaction Barometer; Johnson et al., 2001) and the ECSI (European Customer Satisfaction Index; Eklof, 2000) are all built upon a cumulative definition of satisfaction and operationalized as indices.

Although the development of cumulative satisfaction research and the national indices have greatly facilitated our ability to compare satisfaction across industries, there are notable broad-based comparisons that predate their development. Andreasen and Best (1977), using American consumers, compared customer satisfaction and complaint behavior across thirty-five 
categories and found greater satisfaction with products than with services. Wikstreom (1983) subsequently replicated these results using surveys of both Swedish and American consumers. She also found satisfaction to be lower on average in Sweden. She explains this difference based on general differences in competition and market performance between the two countries, an argument that we echo below.

More recent research replicates and extends these earlier studies. Consistent with Andreasen and Best (1977) and Wikstrom (1983), Fornell et al. (1996) use data from the ACSI to show how satisfaction is systematically higher for competitive product industries than for competitive services and retailers. They further show that satisfaction is higher for these products and services than for public and government agencies. In the baseline ACSI survey, competitive products, competitive services and retailers, and public and government agencies showed average satisfaction index scores of 80, 75 and 64 respectively (on the 0-100 ACSI scale).

\subsection{The case for industry-level differences}

Our discussion of the effects of aggregation suggests that cumulative satisfaction should reveal broad-based differences in performance, as across industries and countries. The key is to find a theoretical basis for expecting differences in satisfaction that can be empirically tested and supported. A relatively straightforward argument is to focus on the prevailing levels of motivation and ability that firms, industries, and countries have to provide customers with a differentiated set of alternatives (Anderson, 1994; Fornell \& Johnson, 1993; Fornell et al., 1996).

Differences in ability have focused on the distinction between product and service production and delivery. Because services are co-produced in the customers presence, at a time and in a place of the customer's choosing, with the customer's input, high levels of service performance should be inherently more difficult to achieve (Fornell \& Johnson, 1993; Gronroos, 1990). Co-production introduces the inconsistencies inherent in human behavior, on part of both the employees and the customer, into the production process itself (such as absenteeism, appearance, mood, physical health, and the fallibility of human judgment). And unlike products, if something goes wrong in the service production process, it is often too late to institute quality controls before the service reaches the customer (Hoffman \& Bateson, 1997).

At the same time, service production allows for intensely personal and customized services that suit a very heterogeneous set of needs (Anderson, Fornell, \& Rust, 1997; Gronroos, 1990). Effective service firms (and customers) may find ways to take advantage of the inherently more flexible nature of service production to more than compensate for the problems of delivering consistent and predictable levels of service quality. Recent research helps reconcile whether service satisfaction should be generally lower due to lower reliability or higher due to customization. Using the American Customer Satisfaction Index data, Johnson and Nilsson (2002) examined 188firms from 30 different industries. They found that, when compared to manufactured goods, problems related to service reliability outweigh the advantages afforded by service customization. As a result, satisfaction is generally lower for services.

Another major distinguishing feature of services is their intangibility. Services cannot be touched or felt in the same way as physical products (Gronroos, 1990; Hoffman \& Bateson, 1997). This intangibility makes it inherently more difficult to display or communicate differentiated service offerings to customers. For example, customers find it particularly difficult to distinguish among the offerings of alternative insurance providers and financial services (Fornell \& Johnson, 1993). Insurance companies and banks provide attributes and benefits that 
customers often have trouble picturing and sampling prior to purchase. This further limits service customers' ability to identify superior alternatives.

With respect to motivation, we expect satisfaction to be higher in those industries and countries where there is greater competition. The more limited the competition, the less incentive an industry or economy has to meet different market segment needs. Traditionally, government or public agencies have enjoyed some degree of restricted competition or monopoly power (such as mail, police, and tax services). The lack of competitive offerings in these markets eliminates the entrepreneurial incentives to target market segments with products or services that better meet their needs. Production and distribution in these cases is more likely to be determined by government regulations or charters (such as meeting certain safety or quality requirements or serving market segments the agency is required to serve). Because customers are relative "hostages" in such a system, they are forced to put up with a higher degree of dissatisfaction. Accordingly, we expect customer satisfaction to be lower among public and government agencies where competition is restricted.

Overall the arguments suggest that satisfaction should be highest for competitive products, lower for competitive services and retailers, and lower still for government and public agencies that represent service firms with limited competition. Theoretically, these arguments are consistent with dynamic theories of competition in economics and marketing (Alderson, 1965; Dickson, 1992; Hunt \& Morgan, 1995). Dynamic theories of competition and market behavior have existed for some time, most notably within the Austrian School (Reekie \& Savitt, 1982). Accordingly, marketing is viewed as a dynamic or ongoing process of attempting to attain a match between heterogeneity in demand and heterogeneity in supply (versus the attainment of a static equilibrium). Industries (products, services, and government agencies) differ in both their motivation and ability to achieve congruence between supply and demand resulting in systematically different levels of satisfaction.

\subsection{The case for country-level differences}

With the exception of Wikstrom's (1983) research and other early comparisons of complaining behavior by Thorelli (see Day \& Perkins, 1992), little attention has been paid to examining satisfaction differences across countries. The question of importance here is whether we expect systematic differences among the three national databases from Germany, Sweden and the US. We argue that the incentives to provide higher customer satisfaction are greater in the United States than in either Germany or Sweden. Even simple observations attest to the greater number of choices of soft drinks, cereals, juices, cars, appliances, and other products offered to US customers.

The differences among the countries are based on multiple socio-political, cultural, and structural factors that affect the incentives to participate in entrepreneurial activities. (Note that the database we use to test our hypotheses uses SCSB, DK and ACSI data from 1994 through 1997. Thus, this section focuses primarily on statistics obtained during or immediately after this time period.) Tax rates are generally higher in both Sweden and Germany than in the US. The tax rate in Sweden in 1995 was

$50.2 \%$ of GDP, compared to $39.1 \%$ in Germany and $27.6 \%$ in the US (Sweden Statistics, 1998). Sweden and Germany also provide more support for the unemployed, which again inhibits incentives to add value through entrepreneurship. In the US, only $0.5 \%$ of GNP is used to support the unemployed compared to 3.8\% and 4.5\% in Germany and Sweden respectively (Institute der Deutschen Wirtschaft, 
1998). There are other structural barriers that limit the incentives to deliver high customer satisfaction in Germany and Sweden vis-a-vis the US. For example, it takes only 3 to 5 months on average to receive permission to develop new production facilities in the US compared to 810 months in either Germany or Sweden (Institute der Deutschen Wirtschaft, 1998). Another barrier is language. Whereas English is among the most used languages in the world, German is less used and only a relatively small number of people know Swedish. This makes it that much more difficult to enter both the Swedish and the German market compared to the US.

It may be argued that many of these structural characteristics reflect underlying cultural differences across the countries. Being "close to the customer" is simply not as strong a value or habit in Europe when compared to the US. A customer orientation, and the economic profits it provides, may simply not be valued to the same degree in countries such as Germany and Sweden where greater emphasis is placed on collective equality. For example, whereas Germans and Swedes place greater value on their positions in society (such as being a physician or professor), Americans place greater value on financial rewards resulting in a greater disparity in incomes in the US than in other developed, western economies (Myrdal, 1973).

This is consistent with Hofstede's $(1980,1984)$ research on cultural differences in quality of life values. In "Culture's consequences", Hofstede compares national cultures on power distance (the extent to which inequality is accepted), individualism (the extent of self versus collective interest), masculinity (well-defined versus overlapping sex roles), and uncertainty avoidance (acceptance of "unstructured, unclear, or unpredictable" situations). One of the biggest differences among the three countries studied here is with respect to individualism. While all three countries score relatively high on the individualism dimension across all of the countries studied, Germany (67) and Sweden (71) score categorically lower than the US (91). Hofstede argues that the more collectivist the culture, the more tightly integrated the society. The more tightly integrated the society, the less individuals are allowed to prosper vis-a-vis society as a whole.

Consistent with these arguments, independent studies rate the overall competitiveness of the US economy above that of either Germany or Sweden. The Index of Economic Freedom (Heritage Foundation, 1998) evaluates different countries on a scale from 1 (very much) to 5 (very little) and rates the US, Germany, and Sweden at 1.90, 2.30 and 2.85 respectively. Similarly, IMD's (1997) World Competitiveness Yearbook rates the US at number 1 in the competitiveness of its overall economy, Sweden is number 16, and Germany is number 19. Overall, these arguments suggest that the motivation and ability to provide customers with a better experience is significantly greater in the US compared to either Germany or Sweden. Thus we expect customer satisfaction to be higher in the US.

\subsection{The case against broad-based comparisons}

In spite of the logic and support for systematic differences in satisfaction, there are strong arguments against making broad-based comparisons. Olander (1977a, 1977b, 1988) argues that aggregate measures of customer satisfaction are inherently problematic and will not reveal meaningful differences. Olander points out that customers may use different yardsticks to judge satisfaction, differ in their knowledge base, adapt to given performance levels, fail to express true dissatisfaction, or strategically express false dissatisfaction. Elster and Roemer (1991) argue that the most important of these is the adaptation problem, also called the "happy slave" or "sour grapes" problem (see also Kahneman \& Varey, 1991). Because customers adapt to the levels of product and service performance available to them, relatively few 
systematic differences in aggregate satisfaction should emerge. Individual differences in the degree of adaptation within and across industries should further compound the problem.

Adaptation is a very real phenomenon. At some level, Olander's concerns should affect the comparability of aggregate satisfaction measures. It may be difficult, for example, to compare satisfaction between customers in relatively wealthy and impoverished countries. At the same time, several considerations suggest that the psychological problems associated with comparing subjective measures of customer satisfaction are overstated. Foremost is the fact that customer satisfaction evaluations do not occur in a vacuum. People evaluate and compare their experience and treatment in one product or service category with that in other categories. In contrast, the adaptation phenomena typically studied in psychology occur in relatively isolated contexts where available stimuli are highly controlled. Moreover, customers live in an increasingly global and information rich economy in which they are increasingly aware of alternative products and services available in the marketplace. That is, customers own benchmarks have grown. And who is in the best position to evaluate customer satisfaction against these benchmarks but customers themselves? The ultimate counter argument to adaptation is straightforward. If observed differences in satisfaction can be explained by underlying differences among industries and countries themselves, the differences are arguably systematic and meaningful (Fornell \& Johnson, 1993).

Another challenge to making broad-based comparisons is that different countries employ different methods for measuring satisfaction. As described in more detail in our empirical study, the Swedish and American indices share a common methodology while satisfaction is measured quite differently in Germany. As a practical matter, variation in methodological practices across industries and countries is not uncommon. What becomes unclear is whether the satisfaction differences observed from country to country are a reflection of underlying differences in the ability and motivation to satisfy customers or simply reflect methodological differences.

\subsection{Hypotheses}

Our discussion of industry-level differences suggests that satisfaction is lower for competitive services and retailers than for competitive physical products, which we state formally as hypothesis one.

H1 Customer satisfaction is lower for competitive services and retailers than for competitive products across countries.

While this hypothesis is supported by ACSI data (Fornell et al., 1996) and is consistent with earlier studies (Andreasen \& Best, 1977; Wikstr€om, 1983), it is not clear that the differences will hold in Sweden and Germany as well.

Our second prediction is that customer satisfaction should be lower among public and government agencies where competition is restricted. Again, while this prediction is supported using data from the ACSI (Fornell et al., 1996), it has not been tested across the three national satisfaction indices studied here. This prediction is stated formally as hypothesis two.

H2 Customer satisfaction is lower for public and government agencies than for more competitive products, services and retailers across countries. 
Finally, we expect systematic differences in satisfaction at the national level. Based on socio-political, cultural and structural differences across countries, we expect customer satisfaction to be higher in the United States than in Germany or Sweden. We state this formally as hypothesis three.

H3 For a given type of industry (products, services and retailers, and government and public agencies), customer satisfaction is lower in Germany and Sweden compared to the United States, while Germany and Sweden are more equal.

\section{Empirical study}

The hypotheses are tested using a database that combines three established national satisfaction indices or barometers in Sweden, Germany, and the US. The SCSB, DK and ACSI surveys were established in 1989, 1992 and 1994 respectively. In the analyses that follow, satisfaction data from each country is analyzed and reported on a 0 to 100-point scale. Not included are more recent indices (such as the ECSI) that limit their coverage to a small number of competitive service industries.

The SCSB and ACSI share a common methodology compared to the DK. Recall that cumulative satisfaction, as a synonym for consumption utility, is a relatively latent variable or construct. This latent satisfaction is reflected in a variety of evaluations and comparisons that customers make, including performance versus expectations, competing products, category norms, and personal desires. The solution within the SCSB and ACSI is to operationalize satisfaction as an index of three survey measures. overall satisfaction, expectancydisconfirmation, and performance versus an ideal product or service in the category. These measures are each rated on 10-point survey scales where higher scale values indicate higher satisfaction. The 0 to 100-point satisfaction scores represent a rescaled, weighted index of the three survey measures. The survey measures are highly correlated in both the SCSB and ACSI and yield reliable satisfaction indices (Fornell, 1992; Fornell et al., 1996).

In contrast, the DK is an aggregation over customers of a single satisfaction-todissatisfaction scale. The scale ranges from 1-5 rather than 1-10. And unlike the Swedish and American scales, the DK is a satisfaction-to-dissatisfaction scale, where lower values represent higher satisfaction and higher values represent higher dissatisfaction. We transform this 1-5 dissatisfaction scale into a 0-100-point satisfaction scale in order to compare it to the SCSB and ACSI.

Another property of the Swedish and American indices is that they are estimated within a system of cause and effect relationships (a causal model). Customer perceptions of quality, value, and expectations are antecedents in both the current ACSI and SCSB models, while complaint behavior and loyalty are viewed as consequences. Both models are designed to predict customer loyalty as the ultimate endogenous variable. Although the DK survey includes measures other than satisfaction, there is no satisfaction model per se (see Johnson et al., 2001 for a review of the national index models).

Our database includes industry-level observations from 1989 through 1997 for the SCSB, 1992 through 1997 for the DK, and 1994 through 1997 for the ACSI. The industries included in the various surveys are listed in Table 1. The industries are classified according to their primary representation as a competitive product industry, competitive service industry, or government and public agency. The classifications are based on standard industrial classification (SIC) codes used in the respective countries with one exception. The ACSI has traditionally classified gas service stations as a manufactured non-durable (a product). To be 
consistent with the other countries, the evolution of gas stations into more cross-category retailers, and recent changes in SIC codes themselves, we classify this industry under competitive services and retailers for all three countries.

This does not mean that industries are identically classified in each case. For example, deregulated industries classified as competitive services in the US (such as Telecommunications and Broadcast TV) remained public agencies in Sweden and Germany over the time period that our data was collected. (More recently, Telecommunications has been deregulated in both Sweden and Germany.)

We use a sample of industry-level satisfaction results taken from the three countries over the time period 1994 through 1997 to test the hypotheses. All of the data is taken from the same four-year period to remove potential confounds due to time. (After 1997, the number of industries measured in the SCSB was reduced by over $50 \%$.) There are a total of 369 industrylevel satisfaction measures available for the analysis. A general linear model was estimated in which country was a three-level factor (Germany, Sweden, United States), industry type was a three-level factor (competitive product, competitive service, government or public agency), and the year the data was collected was used as a covariate. All two- and three-way interactions involving the two factors and the covariate were included in the model.

Because of inherent differences in the industries sampled from country to country, the number of observations varies from cell to cell in the design. The number of observations for products, services, and government and public agencies respectively is 16,86 , and 32 for Sweden, 14, 51, and 33 for Germany, and 49, 64, and 24 for the US. Thus competitive products are more heavily sampled in the US while government and public agencies are more heavily sampled in Sweden and Germany. As a result, any support for $\mathrm{H} 1$ and $\mathrm{H} 2$ creates a difference 
in satisfaction across countries due solely to the type of industries sampled, which confounds

Table 1

Industries surveyed by country

\begin{tabular}{llll}
\hline & Sweden (SCSB) & Germany (DK) & United States (ACSI) \\
\hline Competitive & Automobiles & Automobiles & Apparel \\
products & Food processing & Magazines & Athletic shoes \\
& Newspapers & Newspapers & Automobiles \\
& Personal computers & Personal computers & Beverages - beer \\
& (Business) & Software & Beverages - soft drinks \\
& TV magazines & Consumer electronics \\
& & Food processing \\
& & Household appliances \\
& & Newspapers \\
& & Personal care products \\
& & Personal computers
\end{tabular}

\begin{tabular}{|c|c|c|c|}
\hline & $\begin{array}{l}\text { Airlines } \\
\text { Banks (Business) } \\
\text { Banks (Public) } \\
\text { Clothing retailers } \\
\text { Department stores } \\
\text { Furniture retailers } \\
\text { Gas-service stations } \\
\text { Grocery stores } \\
\text { Insurance (Business) } \\
\text { Insurance (Life) } \\
\text { Insurance (Property) } \\
\text { Mail order companies } \\
\text { Shipping } \\
\text { Travel (Charter) }\end{array}$ & $\begin{array}{l}\text { Airlines } \\
\text { Appliance repair } \\
\text { Auto associations } \\
\text { Banks } \\
\text { Building societies } \\
\text { Car repair services } \\
\text { Charity organizations } \\
\text { Credit card companies } \\
\text { Department stores } \\
\text { Doctors } \\
\text { Drug/variety stores } \\
\text { Elderly care } \\
\text { Electronics/appliance stores } \\
\text { Furniture stores } \\
\text { Gas-service stations } \\
\text { Holiday destinations } \\
\text { Home improvement } \\
\text { centers } \\
\text { Hospitals and clinics } \\
\text { Insurance (Health) } \\
\text { Insurance (Property) } \\
\text { Lawyers } \\
\text { Mail order companies } \\
\text { Parcel delivery } \\
\text { Pharmacies } \\
\text { Religious organizations } \\
\text { Supermarkets } \\
\text { Tour operators } \\
\text { Vehicle inspection }\end{array}$ & $\begin{array}{l}\text { Airlines } \\
\text { Banks } \\
\text { Broadcast TV } \\
\text { Department and discount stores } \\
\text { Electric service } \\
\text { Gas-service stations } \\
\text { Hospitals } \\
\text { Hotels } \\
\text { Insurance (Life) } \\
\text { Insurance (Property) } \\
\text { Motion pictures } \\
\text { Parcel delivery - express mail } \\
\text { Restaurants - fast food } \\
\text { Supermarkets } \\
\text { Telecommunications - long distance } \\
\text { Telecommunications - local }\end{array}$ \\
\hline $\begin{array}{l}\text { Government } \\
\text { and public } \\
\text { agencies }\end{array}$ & $\begin{array}{l}\text { Broadcast TV } \\
\text { Pharmacy } \\
\text { Police }\end{array}$ & $\begin{array}{l}\text { Broadcast TV } \\
\text { Police } \\
\text { Postal service }\end{array}$ & $\begin{array}{l}\text { Internal revenue service } \\
\text { Police - central } \\
\text { Police - suburban }\end{array}$ \\
\hline
\end{tabular}


Table 1 (continued)

\begin{tabular}{lll}
\hline Sweden (SCSB) & Germany (DK) & United States (ACSI) \\
\hline Postal service & Public administration & Postal service \\
(Business) & & \\
Postal service (Public) & Public city transportation & Waste disposal - city \\
Railroad & Railway & Waste disposal - suburban \\
Telecommunications & Telecommunications & \\
(Business) & & \\
Telecommunications & Waste disposal & \\
(Public) & & \\
Wine and spirits & & \\
\hline
\end{tabular}

our test of H3. To address this problem, we test $\mathrm{H} 3$ within (versus across) industry types.

\subsection{Results}

The average levels of satisfaction by country and industry type are presented in Fig. 1. The tests for effects are reported in Table 2. The results reveal significant main effect differences for country $(F=44.084, p<0.001)$ and industry type $(F=28.827, p<0.001)$ but not for year. Planned contrasts of the factor-level means reveal significant satisfaction differences, in the predicted directions, when comparing competitive products and competitive services/retailers $(p<0.01)$ and when comparing competitive services/retailers and government and public agencies $(p<0.001)$. Thus the differences reported in earlier studies are supported using a cross-national sample of three countries using two different measurement methodologies. Similar contrasts reveal differences in satisfaction among the three countries. Recall, however, that these contrasts are confounded by the industries sampled.

Although the main effect differences predicted by $\mathrm{H} 1$ and $\mathrm{H} 2$ are supported, our results also reveal a significant country by industry type interaction ( $F=3.499, p<0.01)$. Looking at Fig. 1 , a couple of observations are driving this interaction. The predicted pattern of results across industry types is very similar in Sweden and the US. In Germany, however, there is little difference between products and services/retailers while government and public agencies rate particularly low. For example, although satisfaction with services and retailers is 65 in both Germany and Sweden, satisfaction with government and public agencies in Sweden is 61 versus 51 in Germany.

A series of planned contrasts was performed to examine more closely the differences in industry type by country. In the US, the predicted differences between products and service and between services and public agencies are significant ( $p<0.05$ and 0.001 respectively). However, when looking only at the Swedish data, none of the contrasts for industry type approached significance. When looking only at the German data, there was a significant difference in the predicted direction between services/retailers and government and public agencies ( $p<0.001)$, a marginally significant difference between products and public and government agencies ( $<<0.07$ ), but no difference between products and services themselves. Thus there are important differences observed in the significance and pattern of industry differences in Germany and Sweden compared to differences found here and reported previously using the US data (Fornell et al., 1996).

Recall that testing $\mathrm{H} 3$ requires a separate analysis because of the differences in the number of industries sampled by industry type across countries. Separate linear models were estimated for the competitive products, competitive services and retailers, and public and 
government agencies. The models included a three-level factor for country, time as a covariate, and the potential interaction between country and time. The estimation results reveal significant main effects for country in each case. Again, however, a series of planned contrasts of the factor-level means is required to more directly test H3. For competitive product industries, satisfaction in Germany and Sweden did not differ while both were significantly lower than the US ( $p$ <.05). The same was true for services and retailers, where Germany and Sweden did not differ, but both showed lower levels of satisfaction than in the US ( $p<0.001)$. For the government and public agencies, satisfaction in the US was higher than satisfaction in Sweden, which was higher than satisfaction in Germany (all contrasts significant at $\mathrm{p}<0.001$ ). Thus H3 is supported with one exception, where public and government agencies were lower in Germany than in Sweden.

Overall our tests provide support for all three hypotheses. At the same time, the results

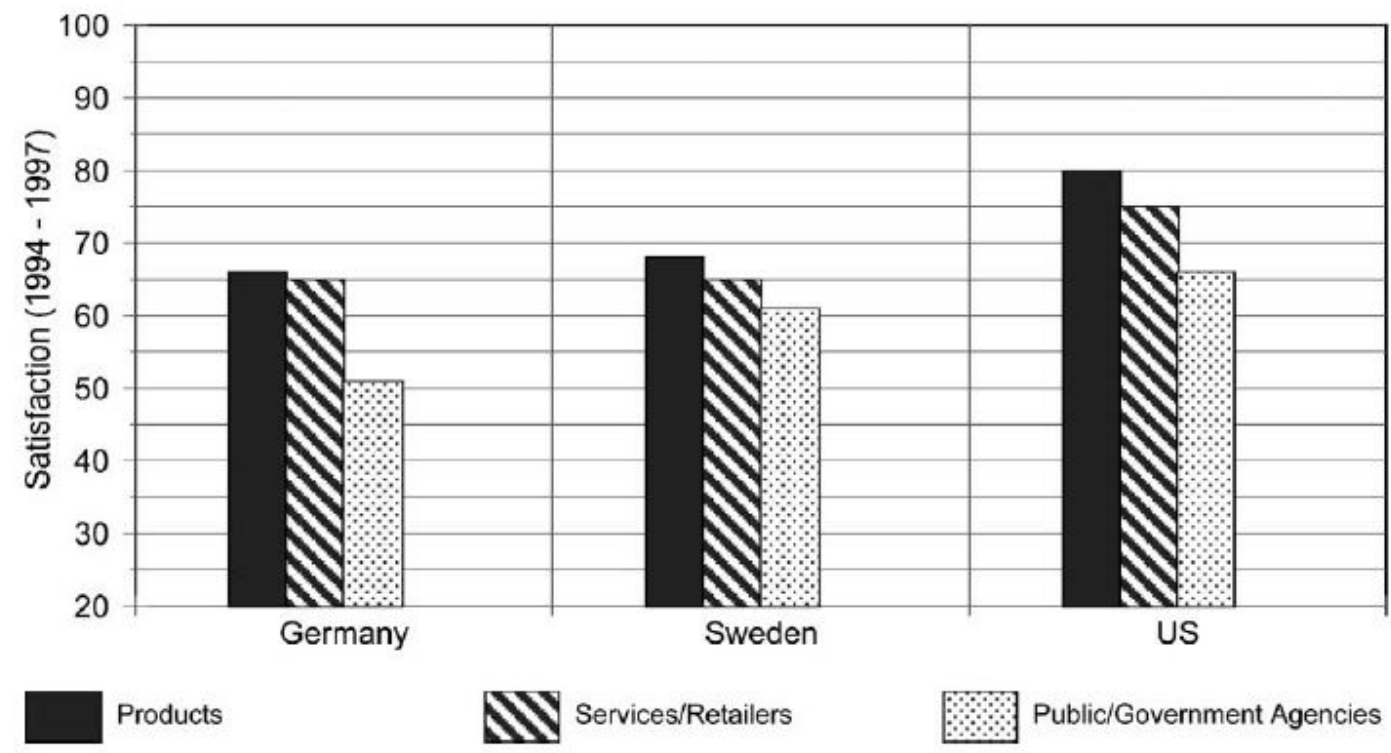

reveal

very different

Fig. 1. Customer satisfaction by country and industry type.

Table 2

Model results for the effects of country, industry type and time on satisfaction

\begin{tabular}{llrlll}
\hline Source & Type III Sum of squares & \multicolumn{1}{c}{ df } & Mean square & $F$ & Sig. \\
\hline Corrected model & 21890.00 & 17 & 1287.65 & 55.214 & 0.000 \\
Intercept & 203903.00 & 1 & 203903.00 & 8743.350 & 0.000 \\
Country & 2056.17 & 2 & 1028.09 & 44.084 & 0.000 \\
Industry Type & 1344.52 & 2 & 672.26 & 28.827 & 0.000 \\
Year & 1.66 & 1 & 1.66 & 0.071 & 0.790 \\
Country X type & 326.36 & 4 & 81.59 & 3.499 & 0.008 \\
Country X year & 84.61 & 2 & 42.30 & 1.814 & 0.165 \\
Type X year & 32.88 & 2 & 16.44 & 0.705 & 0.495 \\
Country X type & & & & & 1.228 \\
X year & 114.54 & 4 & 28.64 & & 0.299 \\
Error & 8185.64 & 351 & 23.32 & & \\
Total & $2 . E+06$ & 369 & & & \\
Corrected total & 30075.60 & 368 & & & \\
\hline
\end{tabular}


magnitudes and patterns of satisfaction differences across countries and industry types. The implications of these results for managers and policy makers are discussed at the end of the paper.

\subsection{Satisfaction in overlapping industries}

Our initial analysis demonstrates both similarities and differences in the patterns and levels of satisfaction across countries. The analysis also raises two important questions. First, recall that the DK uses a very different survey and measurement methodology than that used in both the SCSB and ACSI. It remains unclear just how much the methodological differences may be contributing to the observed satisfaction differences. Second, even though our analysis uses data from the same period of time, different industries are sampled in the different countries. This may also contribute to the results. This prompted us to perform a second analysis to examine more closely just how comparable satisfaction is between countries when the industries overlap.

This was difficult to do in the case of the US where the number of overlapping industries is small relative to Germany and Sweden. And as noted earlier, some of the overlapping industries in the US belong to different industrial organization categories due to their deregulation. In contrast, there are 17 industries that overlap between Germany and Sweden that are identically classified as products, services and retailers, or government and public agencies over the time period that the data was collected (automobiles, gas-service stations, property insurance, newspapers, personal computers, supermarkets, banks, department stores, parcel delivery, mail delivery, telecommunications, police services, airlines, pharmacies, tour operators, railways, and broadcast TV). We thus conducted a separate comparison of these industries for the two countries.

A contrast of these industries is interesting for two reasons. As predicted under $\mathrm{H} 3$, Germany and Sweden should exhibit relatively similar levels of satisfaction by industry. However, as mentioned, very different methodologies are used to provide satisfaction measures in Germany and Sweden. Recall that satisfaction in the SCSB (and ACSI) is based on an index of three survey measures, all rated on 10-point scales (higher scale values=higher satisfaction). Satisfaction in the DK is based on a single 5-point scale where the anchors are reversed (higher scale value = lower satisfaction) albeit re-scaled for analysis. Data is available for most all of these industries in each of the years 1992 through 1997.

We focus on using industry satisfaction in one country to explain industry satisfaction in the other country. To do so, a partial least squares (PLS) model (Fornell \& Cha, 1994; Wold, 1982) was estimated in which satisfaction in Germany was one latent variable used to explain satisfaction in Sweden as another latent variable using the 17 industries as observations. Note that specification of the direction of causation does not affect the model in this case because only two latent variables are involved. The path coefficient is the same as the latent variable correlation. Following a procedure by Fornell and Johnson (1993), the model uses each year's data as a separate satisfaction measure for the industry. This type of model extracts the common covariance in satisfaction over time. Essentially, it models the serial correlation in satisfaction over time for a given industry and country. A small number of industries were not sampled in a given year for Germany $(n=5)$ and Sweden $(n=6)$. In these cases, the industry averages over time, by country, were used as proxies for the missing values in order to provide a complete data matrix. 


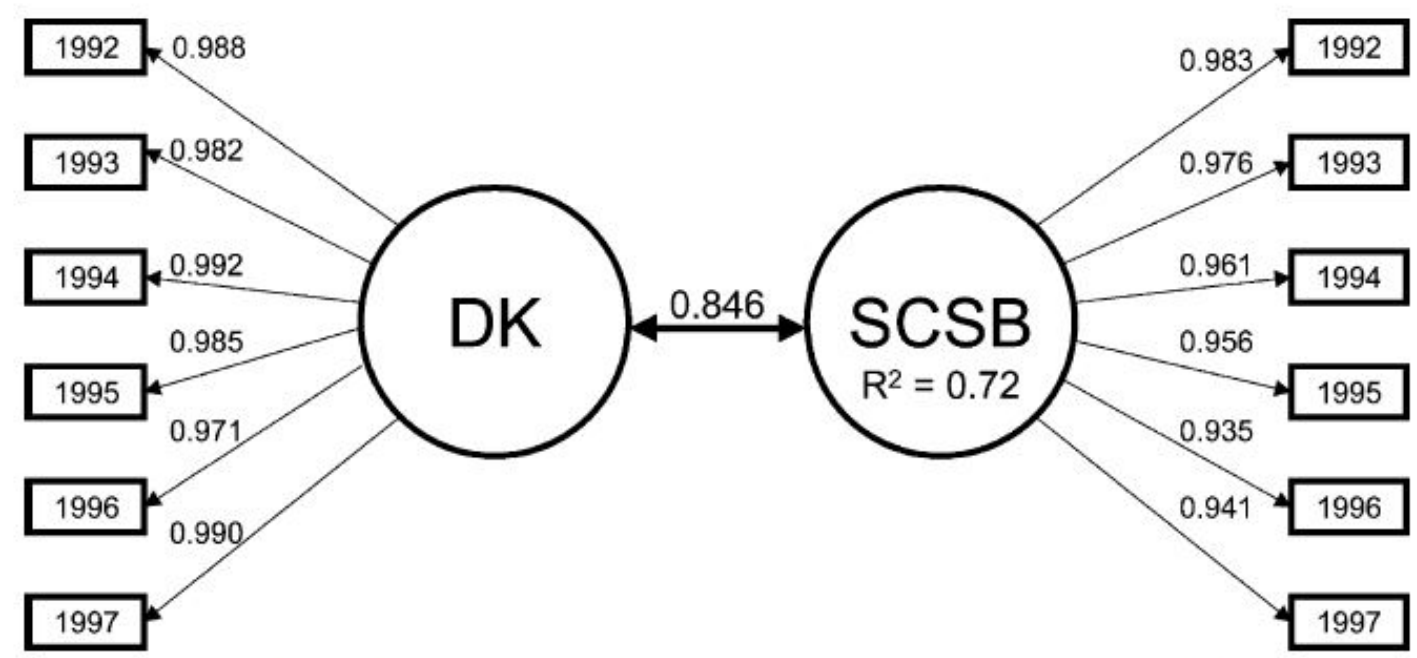

Fig. 2. PLS model for satisfaction in Germany (DK) versus Sweden (SCSB).

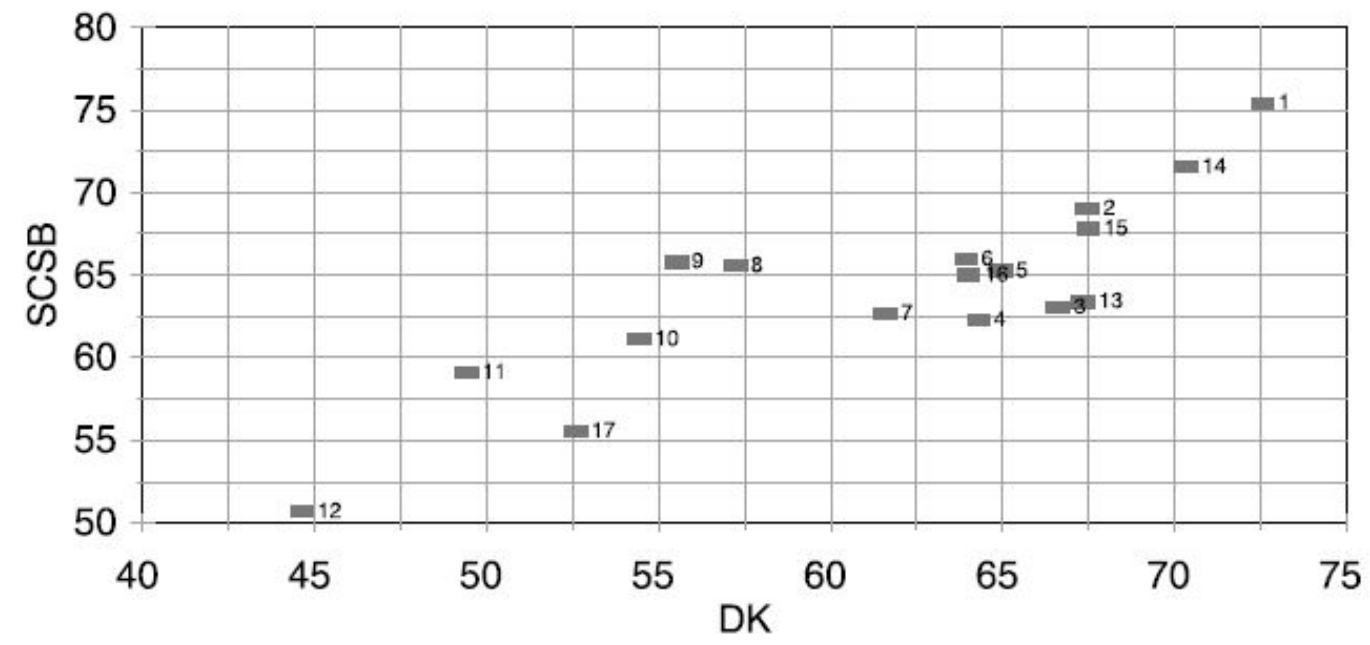

Fig. 3. Satisfaction levels for overlapping industries in Germany and Sweden.

Note: 1 = automobiles, $2=$ gas-service stations, $3=$ property insurance, $4=$ newspapers, $5=$ supermarkets, $6=$ banks, $7=$ department stores, $8=$ parcel delivery, $9=$ postal service, $10=$ telecommunications, $11=$ police, $12=$ broadcast TV, $13=$ airlines, $14=$ pharmacies, $15=$ tour operators, $16=$ mail order companies, and $17=$ railway.

The measurement loadings and latent variable correlation for this model are shown in Fig. 2. The analysis reveals a remarkably high level of correspondence in industry-level satisfaction between the two countries. First, the relatively high and uniform measurement loadings suggest that satisfaction is quite stable over time in both countries, at least for the time period 1992-1997. The loadings range from 0.971 to 0.992 for Germany and from 0.935 to 0.983 for Sweden. The relationship in satisfaction between Germany and Sweden over the time period is also very high as revealed by the latent variable correlation of 0.846 . According to the model, industry satisfaction in Germany explains $72 \%$ of the variation in industry satisfaction in Sweden and vice versa. These results are particularly interesting given the fact that very different measures, as mentioned, are used to operationalize satisfaction in the two countries. 
To illustrate the nature of the relationship, the latent variable scores for each industry are presented in Fig. 3. Foremost, the figure illustrates just how systematic the levels of satisfaction are across the two countries. The results further support the comparability of satisfaction in making broad-based comparisons. They also suggest that, at least at the industry level of aggregation, methodological differences in how satisfaction is measured between Germany and Sweden are not large.

\subsection{Satisfaction differences in Sweden over time}

The results in Fig. 3 also help us to understand some of the differences observed in Fig. 1. Certain public and government agencies in Sweden, particularly postal services and telecommunications, have systematically higher levels of satisfaction than their counterparts in Germany. This prompted a third analysis to examine whether satisfaction for public and government agencies in Sweden has always been so high. In the analyses conducted thus far, satisfaction has not shown great variation over time. Rather, satisfaction differences appear quite stable.

However, these analyses did not incorporate the early years in which satisfaction was measured in Sweden. The evolution of the various indices and barometers has also been quite different in the three countries. Unlike the DK or ACSI, the SCSB was developed as a public policy initiative to provide public agencies (such as the postal service, telephone company, and railway) an opportunity to benchmark their performance against more competitive industries and improve their customer satisfaction. Many public agencies in Sweden have been under pressure for more than a decade to become more customer oriented to compete effectively in a more open market. In the last decade, the politicians have opened up the postal service, telecommunication, and the electricity to more competition. In order to prepare for this, these companies began early on to focus more effort on their customers.

This suggests that the higher levels of satisfaction for public and government agencies in Sweden may not have existed prior to these developments and more closely matched the German industries. The public agencies in Sweden may have improved their customer satisfaction over time relative to more competitive products and services. Put differently, as the public agencies in Sweden started acting more like competitive companies that focus on customers, did they approach competitive services and retailers in aggregate customer satisfaction?

A general linear model was used to test this prediction across the twenty-seven Swedish industries for which a 1989-1996time series is available. The 1997 SCSB was omitted from this analysis because of the relatively large number of missing values during this time period (10 out of 27 industries). These missing values are more problematic in the present analysis given the emphasis on time as a covariate. The missing values create a sampling-based confound between time and industries studied.

Once again satisfaction is the dependent variable. The independent variables were a three-level factor for industry type, a covariate for year, and a type by year interaction. The prediction is that as the public and government agencies in Sweden have become more customer oriented, satisfaction with these agencies has approached the levels of satisfaction achieved for more competitive services. That is, the time by industry type interaction should be significant.

The Swedish time series are illustrated in Fig. 4 and the estimation results are provided in Table 3. Consistent with earlier analyses, there is an overall significant effect of industry type on satisfaction $(F=14.494, p<0.001)$. In support of our prediction regarding time, there is also a marginally significant time by industry type interaction effect $(F=2.801, p<0.063)$. Over time, 
the government and public agencies have been able to "close the gap". There has been an increase in Swedish satisfaction with government and public agencies such that it has approached satisfaction levels for services and retailers. This is particularly evident in the early years of the SCSB. In more recent years, the differences by industry type have been much more stable.

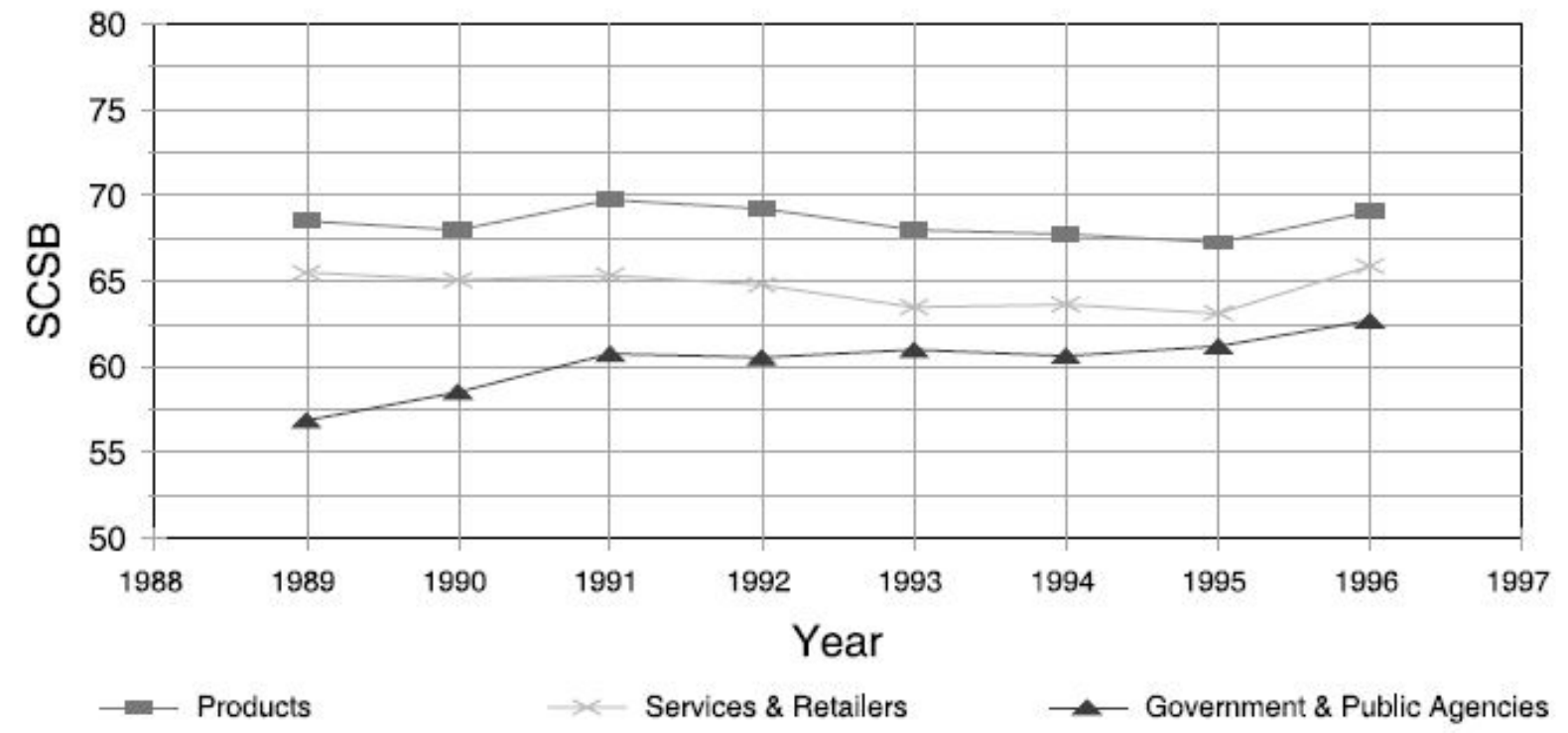

Fig. 4. The SCSB over time.

Table 3

Model Results for the effects of industry type and time on satisfaction in Sweden

\begin{tabular}{llrlll}
\hline Source & Type III Sum of squares & df & Mean square & $F$ & Sig. \\
\hline Corrected model & 1820.59 & 5 & 364.12 & 12.994 & 0.000 \\
Intercept & 139694.00 & 1 & 139694.00 & 4985.110 & 0.000 \\
Industry type & 812.32 & 2 & 406.16 & 14.494 & 0.000 \\
Year & 15.94 & 1 & 15.94 & 0.569 & 0.452 \\
Type X year & 157.01 & 2 & 78.50 & 2.801 & 0.063 \\
Error & 5884.68 & 210 & 28.02 & & \\
Total & 885339.00 & 216 & & & \\
Corrected total & 7705.28 & 215 & & & \\
\hline
\end{tabular}

\section{Discussion}

Obviously great care must be taken when comparing customer satisfaction across industries and countries. Yet our study and results suggest that observed differences in satisfaction across Germany, Sweden and the United States are relatively predictable and meaningful. The differences are driven largely by the degree to which customers are provided with market offerings that satisfy their needs. Satisfaction is systematically higher for products, more intermediate for services and retailers, and lower for public agencies across the industries 
studied in the three countries. Satisfaction is also predictably higher in the United States than in Germany or Sweden. The results have both management and public policy implications.

\subsection{Management implications}

From a managerial standpoint, our results suggest that national satisfaction indices both within and across countries. Satisfaction measures have been used for some time to benchmark the performance of product against product and firm against firm. Our results show their value in benchmarking the performance of industry against industry or even one economy against another. At the same time, evaluating the differences requires consideration of a variety of economic as well as cultural differences. For example, higher satisfaction scores in the United States compared to Germany and Sweden are predictable based on cultural differences among the countries.

Another important managerial implication concerns the use of different methodologies when making broad-based comparisons. The national survey methodology used to measure satisfaction in Sweden and the US is different from that used in Germany. The German index is based on a single rather than multiple measures, fewer scale points, and is scaled in the opposite direction. This problem is not uncommon in practice where very different scales and measures are used across firms, industries and countries. At least at the level of aggregation studied here, our results suggest that the methodological differences do not appear to explain the observed differences in satisfaction. After rescaling, industry-level satisfaction in Germany and Sweden is predictably very similar. Thus managers should not assume that methodological differences necessarily limit the ability to benchmark satisfaction across industries and countries.

Finally, managers should understand that the industry-level differences that we observe are due to underlying differences in the ability and motivation to satisfy customers. Because services involve a co-production process that is inherently less reliable than is the production and delivery of physical products, customer satisfaction is generally lower for services. The intangibility of services, which makes service quality more difficult to communicate and understand, contributes to this difference. Thus it may be unrealistic for service firms to benchmark and target the satisfaction levels achieved by admired peers that produce physical goods.

\subsection{Public policy implications}

The results have important implications for policy makers as well. Tracking customer satisfaction could prove essential for a country's competitiveness and have an effect on its policies. In this sense, the development of a more open European Economic Community and a common currency should benefit the ability of European companies to add value and compete effectively with their US counterparts. The national satisfaction indices are a valuable tool to help policy makers to evaluate this competitiveness, as reflected in changes in customer satisfaction over time. At the same time, as Hofstede, Myrdal, Olander and others have argued, culture matters. Policy makers, like their counterparts in the private sector, must consider cultural differences when developing their policies and benchmarking one industry sector against another or one economy against another.

Our results also demonstrate that public policy can make a difference. Customer satisfaction for government and public agencies is generally higher in Sweden compared to Germany. But this was not always the case. Our analysis of the Swedish time series reveals that satisfaction levels are not necessarily "set in stone" by industry type. The national 
satisfaction index in Sweden is different in that it was initiated by government or public agencies as a way to help close the gap with more competitive industries. The Swedish results support this contention where public agencies have, over time, approached the level of satisfaction provided by more competitive service industries.

4.3. Limitations and future research

The primary limitation of the present study is that the three countries involved in our study may all be considered relatively similar from a global perspective. Although systematic differences emerge, Sweden, Germany and the US are all relatively competitive and developed Western economies. It will be interesting to see how satisfaction results generalize as the cultural and economic differences inherent in the national indices grows to include other more dissimilar countries. Problems related to different level of adaptation and cultural differences will only become more salient as the scope of the indices increases. Yet our study and results suggest that satisfaction, as a proxy for consumption utility, is more comparable on a broadbasis than many ever imagined. 


\section{References}

1. Alderson, W. (1965). Dynamic marketing behavior. Homewood, IL. Irwin.

2. Anderson, E. W. (1994). Cross-category variation in customer satisfaction and repurchase. Marketing Letters, 5, 19-30.

3. Anderson, E. W., Fornell, C., \& Rust, R. T. (1997). Customer satisfaction, productivity and profitability. Differences between goods and services. Marketing Science, 16(2), 129145.

4. Andreasen, A. R., \& Best, A. (1977). Consumers complain - does business respond? Harvard Business Review, 55, 93-101.

5. Churchill, G. A., Jr. \& Surprenant, C. (1982). An investigation into the determinants of customer satisfaction. Journal of Marketing Research, 19, 491-504.

6. Day, R. L., \& Perkins, D. S. (1992). Roots. A folk history of the consumer satisfaction literature. Journal of Consumer Satisfaction, Dissatisfaction and Complaining Behavior, 5, 223-227.

7. Dickson, P. R. (1992). Toward a general theory of competitive rationality. Journal of Marketing, 56, 69- 83.

8. Ekloof, J. A. (2000). European Customer Satisfaction Index pan-European telecommunication sector report-Based on the pilot studies, 1999. Stockholm, Sweden. European Organization for Quality and European Foundation for Quality Management.

9. Elster, J., \& Roemer, J. E. (1991). Introduction. In J. Elster \& J. E. Roemer (Eds.), Interpersonal comparisons of well-being (pp. 1-16). Cambridge. Cambridge University Press.

10. Epstein, S. (1979). The stability of behavior. I. On predicting most of the people much of the time. Journal of Personality and Social Psychology, 37, 1097-1126.

11. Epstein, S. (1980). The stability of behavior. II. Implications for psychological research. American Psychologist, 35(9), 790-806.

12. Fornell, C. (1992). A national customer satisfaction barometer. The Swedish experience. Journal of Marketing, 56, 6-21.

13. Fornell, C., \& Cha, J. (1994). Partial least squares. In R. P. Bagozzi (Ed.), Advanced Methods of Marketing Research (pp. 52-78). Cambridge, MA. Blackwell.

14. Fornell, C., \& Johnson, M. D. (1993). Differentiation as a basis for explaining customer satisfaction across industries. Journal of Economic Psychology, 14(4), 681-696.

15. Fornell, C., Johnson, M. D., Anderson, E. W., Cha, J., \& Bryant, B. E. (1996). The American Customer Satisfaction Index. Nature, purpose and findings. Journal of Marketing, 60, 718.

16. Gronroos, C. (1990). Service management and marketing. Managing the moments of truth in service competition. Lexington, MA. Lexington Books. Heritage Foundation (1998). http.//www.heritage.org/index/.

17. Hoffman, K. D., \& Bateson, J. E. G. (1997). Essentials of services marketing. Fort Worth, TX. Dryden Press.

18. Hofstede, G. (1980). Culture's consequences. International difference in work-related values. Beverly Hills, CA. Sage.

19. Hofstede, G. (1984). The cultural relativity of the quality of life concept. The Academy of Management Review, 9, 389-398.

20. Hunt, S. D., \& Morgan, R. M. (1995). The comparative advantage theory of competition. Journal of Marketing, 59, 1-15. 
21. IMD (1997). World competitiveness yearbook. IMD, Lausanne, Switzerland.

22. Institute der Deutschen Wirtschaft (1998). http.//www.iwkoeln.de/iwk/static/default.htm.

23. Johnson, M. D. (1995). The four faces of aggregation in customer satisfaction research. In F. Kardes \& M. Sujan (Eds.), Advances in consumer research (vol. 22, pp. 89-93). Provo, UT. Association for Consumer Research.

24. Johnson, M. D. (2001). Customer satisfaction. In N. J. Smelser \& P. B. Baltes (Eds.), International encyclopedia of the social and behavioral sciences (pp. 3198-3202). Amsterdam, The Netherlands. Elsevier.

25. Johnson, M. D., Anderson, E. W., \& Fornell, C. (1995). Rational and adaptive performance expectations in a customer satisfaction framework. Journal of Consumer Research, 21, 128-140.

26. Johnson, M. D., \& Fornell, C. (1991). A framework for comparing customer satisfaction across individuals and product categories. Journal of Economic Psychology, 12(2), 267286.

27. Johnson, M. D., Gustafsson, A., Andreassen, T. W., Lervik, L., \& Cha, J. (2001). The evolution and future of national customer satisfaction index models. Journal of Economic Psychology, 22(2), 217-245.

28. Johnson, M. D., Nilsson, L., (in press). The importance of reliability and customization from goods to services. Quality Management Journal.

29. Kahneman, D., \& Varey, C. (1991). Notes on the psychology of utility. In J. Elster \& J. E. Roemer (Eds.),Interpersonal comparisons of well-being (pp. 127-163). Cambridge. Cambridge University Press.

30. Katona, G. (1975). Psychological economics. New York. Elsevier.

31. Meyer, A. (1994). Das Deutsche kundenbarometer 1994. Munchen, Germany. LudwigMaximilians- Universitat Munchen.

32. Meyer, A. (1996). The German customer satisfaction barometer. Quality and satisfaction 1995. Dusseldorf, Germany. German Marketing Association.

33. Myrdal, G. (1973). Against the stream. Critical essays on economics. New York. Vintage Books.

34. Oliver, R. L. (1997). Satisfaction. A behavioral perspective on the consumer. New York. McGraw-Hill.

35. Olander, F. (1977a). Can consumer dissatisfaction and complaints guide public consumer policy? Journal of Consumer Policy, 1, 124-137.

36. Olander, F. (1977b). Consumer satisfaction - A skeptic's view. In H. K. Hunt (Ed.), Conceptualization and measurement of consumer satisfaction and dissatisfaction (pp. 409-452). Cambridge, MA. Marketing Science Institute.

37. Olander, F. (1988). Consumer satisfaction/dissatisfaction and the consumer interest. In E. S. Maynes (Ed.), The frontier of research in the consumer interest (pp. 753-759). Columbia, MO. American Council on Consumer Interests.

38. Poiesz, T. B. C., \& von Grumbkow, J. (1988). Economic well-being, job satisfaction, income evaluation, and consumer satisfaction. An integrative attempt. In W. F. Van Raaij et al. (Eds.), Handbook of economic psychology (pp. 570-593). Dordrecht, The Netherlands. Kluwer Academic Publishers.

39. Reekie, D., \& Savitt, R. (1982). Marketing behavior and entrepreneurship. A synthesis of Alderson and Austrian economics. European Journal of Marketing, 16(1), 55-66.

40. Simon, J. L. (1974). Interpersonal welfare comparisons can be made and used for redistribution decisions. Kyklos, 27, 63-98. 
41. Sweden Statistics (1998). http.//www.scb.se/eng/index.asp.

42. Warneryd, K.-E. (1988). Economic psychology as a field of study. In W. F. Van Raaij et al. (Eds.),Handbook of economic psychology (pp. 2-41). Dordrecht, The Netherlands. Kluwer Academic Publishers.

43. Wikstrom, S. (1983). Another look at consumer dissatisfaction as a measure of market performance.Journal of Consumer Policy, 6(1), 19-35.

44. Wold, H. (1982). Systems under indirect observation using PLS. In C. Fornell (Ed.), A second generation of multivariate analysis. Methods (pp. 325-347). New York. Praeger. 